International Research Journal of Engineering, IT \& Scientific Research
Available online at https://sloap.org/journals/index.php/irjeis/
Vol. 4 No. 6, November 2018, pages: $55 \sim 66$
ISSN: 2454-2261
https://sloap.org/journals/index.php/irjeis/article/view/377

\title{
Development of Interactive Mathematics Learning Media on Statistics Topic for Hearing-impaired Student
}

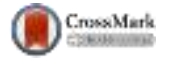

\author{
I Made Suarsana a \\ Gusti Ayu Mahayukti ${ }^{\text {b }}$ \\ I Komang Sudarma ${ }^{c}$ \\ I Nyoman Bayu Ary Yoga ${ }^{d}$
}

Article history:

Received: 4 April 2018

Accepted: 30 September 2018

Published: 13 November 2018

\section{Keywords:}

Hearing-impaired students;

Interactive media;

Mathematics learning;

Sign language;

Statistics;

\begin{abstract}
This research is a development research carried out to answer the problem of scarcity of special mathematics learning resources for hearing-impaired students. Through this research will be developed interactive mathematics learning media which (i) contains material about Statistics in Class VII, (ii) displays abstract mathematical objects in visual form, (iii) displays interesting visualizations according to the characteristics of hearing-impaired students, (iv) equipped with sign language, (v) hierarchically arranged which is ordered where students will be able to move to the next page if they have been able to give the right response/answer, (vi) equipped with evaluation with direct feedback. The research was conducted through four stages, adopting a 4-D development research design (define, design, develop, and disseminate). The quality of the media produced is determined based on expert validation. The results of expert validation indicate that the devices developed have met very valid criteria. In order for the device to meet eligibility criteria, the research needs to be continued so that practical and effective criteria are met through limited and broad trials.
\end{abstract}

2454-2261 ${ }^{\circledR}$ Copyright 2018. The Author. This is an open-access article under the CC BY-SA license (https://creativecommons.org/licenses/by-sa/4.0/) All rights reserved.

\section{Author correspondence:}

I Made Suarsana,

Mathematics Education Program Studies, Ph: +6281916239933

Universitas Pendidikan Ganesha, Singaraja, Bali, Indonesia

Email address: suarsana1983@gmail.com

\footnotetext{
${ }^{a}$ Ganesha University of Education, Singaraja, Bali, Indonesia

${ }^{\mathrm{b}}$ Ganesha University of Education, Singaraja, Bali, Indonesia

${ }^{c}$ Ganesha University of Education, Singaraja, Bali, Indonesia

${ }^{\mathrm{d}}$ Ganesha University of Education, Singaraja, Bali, Indonesia
} 


\section{Introduction}

The mathematical learning objectives of hearing-impaired students (HiS) are not much different from normal students, namely to equip them to be able to think logically, analytically, systematically, critically, creatively, and have the ability to cooperate (Mulyadi, 2015). But the mathematics learning outcomes of hearing-impaired students are still very low (Yang et al., 2007). This is reinforced by Tanridiler et al (2015) statement that some of the results of the study indicate the learning performance of hearing-impaired students is low and far behind when compared to normal students of their age. For normal students, Widana et al., (2018), mathematics is a subject that is considered difficult. For hearing-impaired students, the problem will become even more complex due to hearing loss (Tanridiler, 2015). Some barriers to learning for hearing-impaired students include: weakness in accessing information (Rapin, 1986; Nunes \& Moreno, 2002), limited communication with other teachers/students (Saud and Nasruddin, 2016; Chen, 2014) and low learning motivation because they feel they are not comfortable and sometimes frustrating in expressing ideas/questions (Liu et al., 2006).

One of the topics of learning mathematics at the Special Junior High School is statistics. In Class VII, in statistics discussed presenting data using tables and diagrams. Of course, mathematics learning for hearing-impaired students certainly cannot be equated with normal students. Hearing-impaired students are often called visual learners because they absorb more information by looking at their visual senses (Pariatin \& Yuda, 2014; Chen, 2014). Therefore, learning material should be made simple and equipped with visual representations (Malatista \& Sediyono, 2011; Hopkins \& Moore, 2010). The use of media in mathematics learning will maximize the sense of sight as a tool in receiving information stimulation for the implementation of mathematics learning so students can more easily understand mathematical concepts and be able to minimize communication barriers between teachers and students. And as the development of information and communication technology today, it is also possible to develop interactive learning media by accommodating the limitations of hearing-impaired students.

Interactive media is a multimedia learning environment such as interactive video and computer-assisted learning, computer-assisted instruction (CAI). In CAI, students interact directly with interactive multimedia, such as simulations, games, and drill and practice. Students not only see pictures and hear sounds but can provide an active response. Some of the advantages of using interactive multimedia are: (a) consisting of various media formats (multiple representations); (b) Encouraging student active participation; (c) learners can begin learning flexibly; and (d) can provide a more real learning experience in the form of simulations or imitations of actual phenomena (Kirna, 2011). Some research results related to the use of interactive media in learning hearing-impaired students show that there is a significant influence on student motivation and learning outcomes (Suwastarini et al., 2015; Malatista \& Sediyono, 2011; Marzal, 2014). Although the position of the learning media for hearing-impaired students is very vital, its availability is still scarce, moreover the media is specifically for mathematics learning (Mohid \& Zin, 2010). Therefore, through this research would be developed interactive mathematics learning media for Deaf Special Junior High School Students.

The interactive media developed in this study used several supporting software such as Lectora Inspire, Active Inspire, Camtasia Studio, Geogebra and other supporting software so that the media will load material featuring learning tutorial videos (made with Camtasia Studio, Active Inpsire) and dynamic worksheets that allow students explore the media (made with GeoGebra), and load a problem exercise to measure the mastery of the material with immediate feedback. The work environment that is displayed by the media is interactive, meaning that to be able to continue the page material to the next page, students must be able to give the correct response to the questions displayed in the media. Preparation of the material as far as possible must be able to display abstract mathematical concepts in visual form, using simple language according to the language skills of hearing-impaired students, attractive visualization, and equipped with sign language. Thus, the focus of this research is to answer the question: How is the validity of interactive mathematics learning media for deaf special junior high school students developed?

\section{Materials and Methods}

\subsection{Research Design}

This research is a type of development research that follows the path of 4-D development, namely define, design, develop, and disseminate (Thiagarajan et al., 1974). In this paper, it will be presented until the development stage, which is the creation of prototype teaching materials that have passed validation/expert testing. 
2.2 Research Procedure

The first step is defined. At the defining stage carried out initial analysis and curriculum analysis. In the initial analysis, researchers identified problems that occurred in the field in learning mathematics, especially statistical material for presenting VII grade data in Deaf Special Junior High School. Based on observations and interviews with class VII teachers identified problems, including: 1) students have difficulty in determining the frequency of data; 2) students experience difficulty in determining the wide portion of a circle in percent and angle; 3 ) the availability of media and teaching aids in statistical learning is very limited in the presentation of data so learning tends to use the lecture method. The results of the curriculum analysis obtained the limitations of statistical material for presenting data for class VII SLB B Curriculum 2013. The material was divided into several submissions, including presentation of data in table form, presentation of data in the form of line graphs, presentation of data in bar and circle diagrams.

The second step is designed. In the design phase, media design is carried out in terms of content, appearance, and learning strategies by arranging flowcharts and storyboards as well as initial products from interactive media. The media design developed in this study can at least (i) contain material about Statistics in Class VII, (ii) display abstract mathematical objects in visual form, (iii) simplify the material in accordance with the language skills of hearing-impaired students, (iv) display visualization interesting in accordance with the characteristics of hearingimpaired students, (v) equipped with sign language, (vi) hierarchical arrangement that is ordered where students will be able to move to the next page if they have been able to provide appropriate responses/answers, (vii) supplemented with evaluation with feedback directly. After the flowchart is compiled, the storyboard is compiled, and the storyboard is realized to become Prototype I by using computer application assistance. The applications used in making this learning multimedia are Lectora Inspire, GeoGebra, Camtasia Studio, and Photoshop.

The third step is developed. This stage aims to produce final prototypes from the media. To produce good learning media, several stages are carried out, namely expert/validity tests, product revisions, and limited trials. The validity test aims to determine media validity in terms of media validity, the validity of learning design, material validity, and language validity.

The fourth step is disseminated. The dissemination stage is carried out to promote development products so that they can be accepted by users, both individuals, groups, or systems. The dissemination process can be carried out in various ways such as done in other classes with the aim of knowing the effectiveness of the use of the device in the learning process. Dissemination can also be done through a process of transmission to related learning practitioners in a particular forum. In this paper, only the product development results are presented until the developing stage.

\subsection{Participant}

This study involved 5 students from Singaraja State Junior High School B grade VII 2016/2017 in conducting limited trials. The selection of Singaraja State Junior High School B as a place for limited trials is based on consideration of ease of access so that fluency in research can be guaranteed. In addition, the facilities and infrastructure contained in the school are able to accommodate the implementation of the use of multimedia interactive mathematics learning of statistical material in the presentation of data in classroom learning.

\subsection{Research Instrument}

The data collected in this study is in the form of data quality of learning media. The data collection instrument used is the validation sheet. The validity of learning media can be seen from the aspect of content feasibility, linguistic aspects, presentation aspects, and graphic aspects. Adopted from Akpinar (2008), Yamasari (2010), \& Wahono (2006). The validity of content feasibility is seen from the suitability of the media with core competencies and basic competencies, conformity with children's development, conformity with the needs of instructional materials, the truth of the substance of learning materials, the benefits of adding insight, conformity with moral values and social values. Language validity includes readability, clarity of information, conformity with good and correct Indonesian language rules, and effective and efficient use of language (clear and concise). Presentation validity includes clarity of purpose (criteria) to be achieved, the order of presentation, giving motivation, attractiveness, interaction (giving stimulus and respond), completeness of information. Graphic validity includes, among others, font usage, type and size, layout, illustrations, images, photos, and display design.

Suarsana, I. M., Mahayukti, G. A., Sudarma, I. K., \& Yoga, I. N. B. A. (2018). Development of interactive mathematics learning media on statistics topic for hearing-impaired student. International Research Journal of

Engineering, IT \& Scientific Research, 4(6), 55-66. https://doi.org/10.21744/irjeis.v4n6.377 
Data Analysis Technique

The dictate is said to be valid if the average minimum rating is in the valid category of the four categories prepared, namely invalid, less valid, valid, and very valid.

Table 1

Media Validity Criteria

\begin{tabular}{cc}
\hline Score & Criteria \\
\hline $3,25<\bar{X} \leq 4,00$ & Very Valid \\
$2,50<\bar{X} \leq 3,25$ & Valid \\
$1,75<\bar{X} \leq 2,50$ & Less valid \\
$1,00 \leq \bar{X} \leq 1,75$ & Not valid \\
\hline
\end{tabular}

(Arikunto, 2006)

\section{Results and Discussions}

\subsection{Result}

\section{a) Media Development Result}

The initial display that appears when multimedia is run looks like Figure 1 (a). In the start page there are 3 buttons that can be selected, namely: (1) the "Start Multimedia" button, which when clicked brings up the main menu for learning; (2) the "Developer Profile" button to display information on the developer identity of multimedia interactive mathematics learning material for data presentation; (3) the "Exit" button is useful for closing the multimedia learning window. When students choose the "Start Multimedia" button the main menu page appears that looks like Figure 1 (b). On the main menu, the page contains 3 main menu buttons, namely Competence, Material, and Practice Questions. In addition, on this page, there are also 3 small buttons in the upper right corner of multimedia that have functions in sequence, namely to go to the start page, symbols instruction, and exit multimedia.

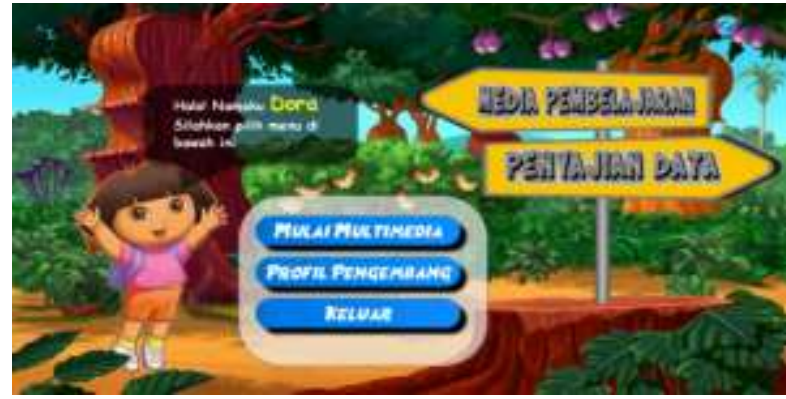

Figure 1. (a) Front-page Preview

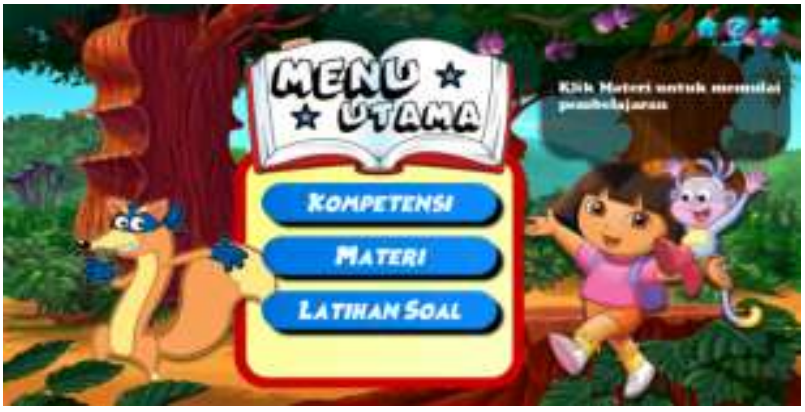

(b) Main Menu Preview

When students choose "Material" in the main menu, students will see an introductory page that displays a video that contains an initial explanation of what students will learn in interactive mathematics learning multimedia of data presentation statistics, as shown in Figure 2 (a). After students to the next page, students will display a map that will guide students to learning material that can be completed by students one by one in sequence. The material map display will look like Figure 2 (b). 


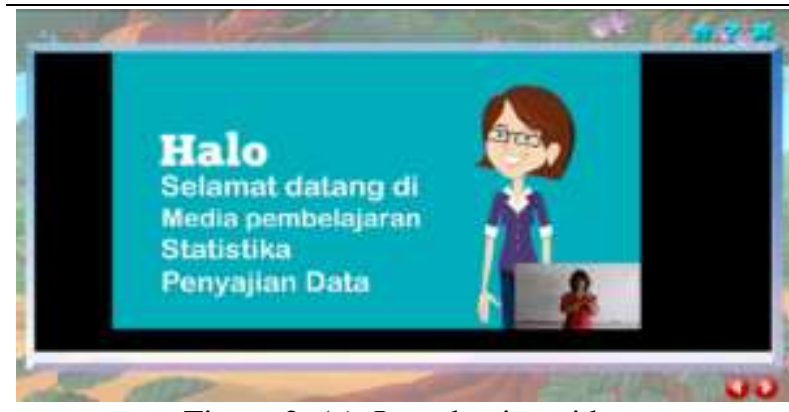

Figure 2. (a) Introduction video

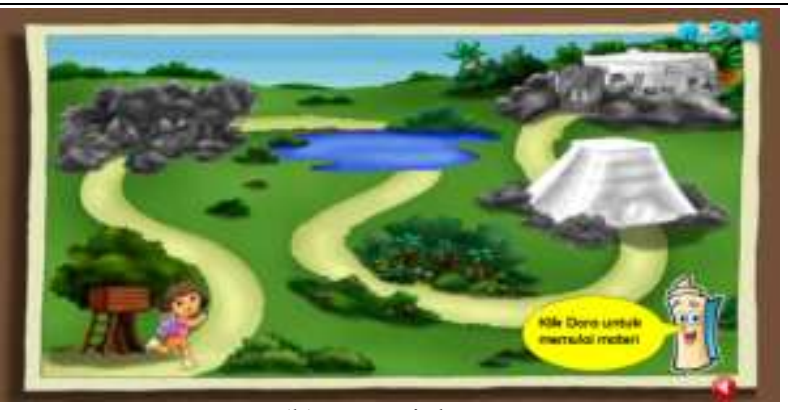

(b) Material map

In the first stage, students will be asked to complete the first submission, namely the presentation of data with tables that students have previously studied at the elementary level. The display of the data presentation page with the table looks like Figure 3. Students must complete each problem contained in the material to be able to proceed to the next sub material.
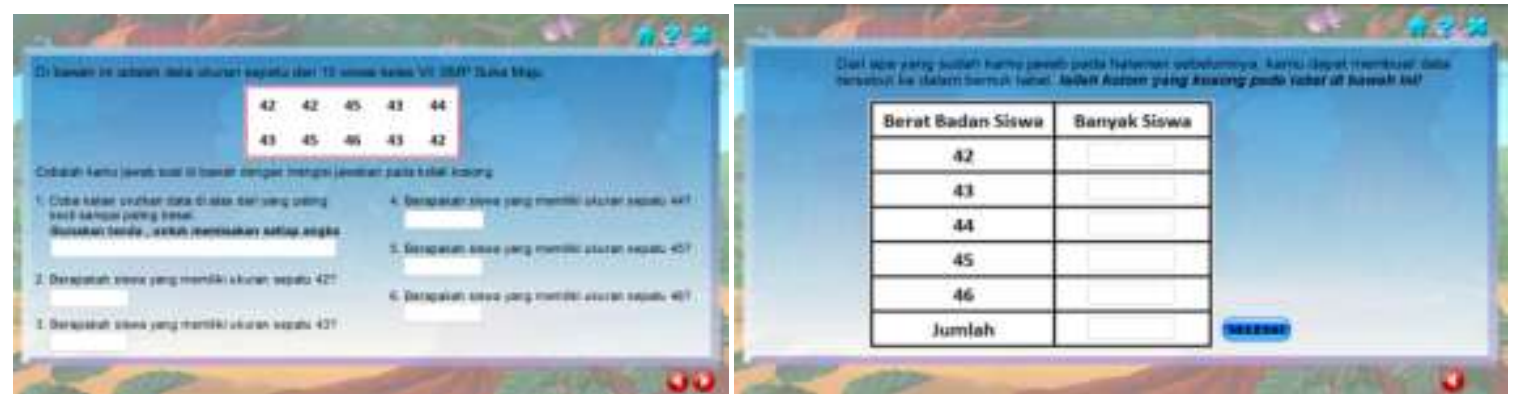

Figure 3. Data presentation with table

After students complete all the sub-material provided starting from presenting data with tables to presenting data with pie charts, students will be directed to the exercise page to measure students' understanding of the material learned from the multimedia learning. In the problem exercise, there are 20 questions with multiple choice objective forms with an allocation of 90 minutes. Students can answer these questions sequentially or randomly, which students can choose by clicking on the question number found on the left of the question. A small white circle on the right side of the question number in the question number column indicates the question has not been answered, on the contrary, if the question has been answered then the circle will be black. To be declared a pass, in answering a question exercise, students must get a minimum score of 70. The appearance of the problem exercise looks like Figure 4.

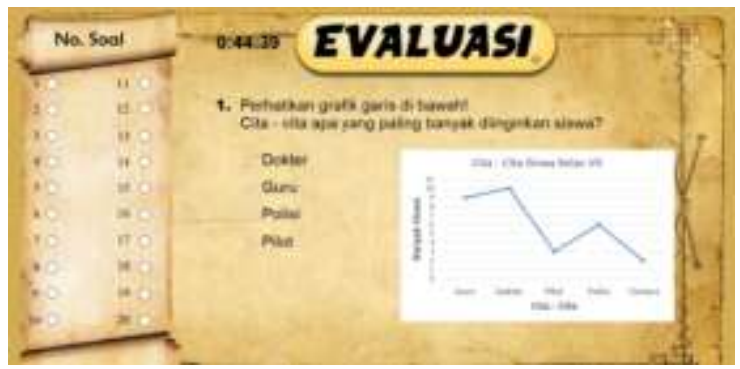

Figure 4. Exercise

After completing all the questions students are directed to press the "Finish" button. When students press the "Finish" button an exercise results page will be displayed that contains the score. In the exercise results, page students have a "check answer" button which when selected by students will bring up a flat number of student questions with a description of which questions are right and wrong, so students are able to know in what number they are wrong in answering. If in working on the problem students run out of time, then the student's score will be immediately

Suarsana, I. M., Mahayukti, G. A., Sudarma, I. K., \& Yoga, I. N. B. A. (2018). Development of interactive mathematics learning media on statistics topic for hearing-impaired student. International Research Journal of Engineering, IT \& Scientific Research, 4(6), 55-66. https://doi.org/10.21744/irjeis.v4n6.377 
processed and displayed on the exercise results page. The exercise page can be seen in Figure 5 (a) and the student's correct or incorrect answer page can be seen in Figure 5 (b).

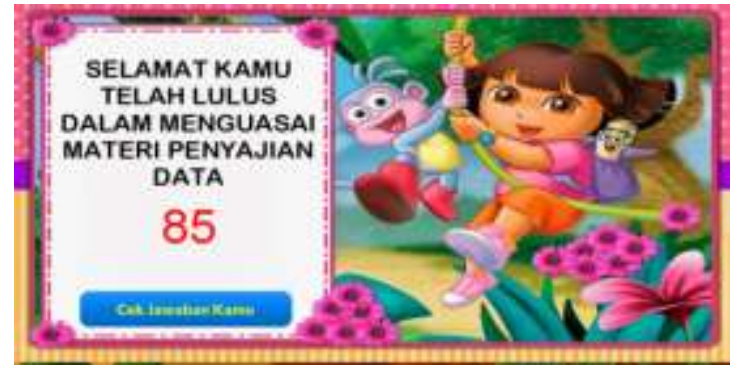

Figure 5. (a) Exercise Preview

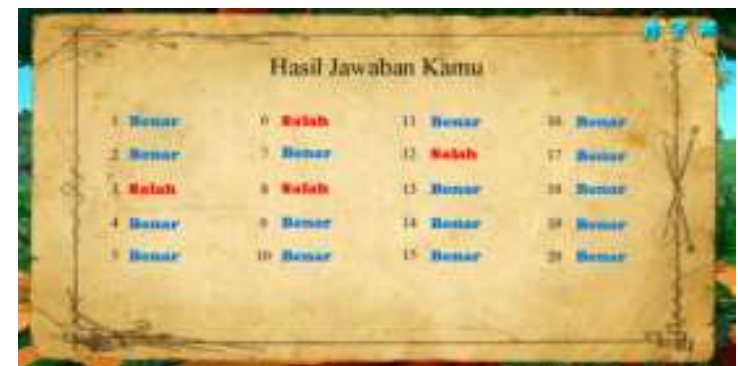

(b) Answer Feedback

Multimedia learning that author developed was packaged in the form of CD (Compact Disk) which can be accessed through a computer or laptop with Windows 7,8 , or 10 operating system. The author also made a general user guide about using developed multimedia

\section{b) Results of Media Validation}

Prototype 1 produced at this stage tested its validity by 5 experts including 1 expert for media validity, 1 expert for learning design validity, 2 experts for material validity, 1 expert for language validity. Based on the results of this validation test, revisions were made to obtain learning media in the form of prototype 2 . The results of the validation in each aspect were presented as follows:

Table 2

The Results of Material Aspect Validation

\begin{tabular}{|c|c|c|c|c|}
\hline No. & Material Assesment Aspect & $\begin{array}{c}\text { Expert Score } \\
1\end{array}$ & $\begin{array}{c}\text { Expert Score } \\
2\end{array}$ & $\begin{array}{l}\text { The Average of } \\
\text { Expert Score }\end{array}$ \\
\hline 1. & Material Suitability with KI/KD & 4 & 4 & 4 \\
\hline 2. & Concept Truth & 4 & 3 & 3.5 \\
\hline 3. & Material Actualization & 3 & 3 & 3 \\
\hline 4. & Material Systematics & 4 & 4 & 4 \\
\hline 5. & Suitability between material with student growth level & 3 & 3 & 3 \\
\hline 6. & Sufficiency of material to achieve learning purpose. & 4 & 3 & 3,5 \\
\hline 7. & Breadth and depth of material & 3 & 3 & 3 \\
\hline 8. & The examples accuracy to clarify the material & 4 & 4 & 4 \\
\hline 9. & Explication of question formulation & 4 & 4 & 4 \\
\hline 10. & Level of question difficulty & 4 & 4 & 4 \\
\hline & Total Score & 37 & 35 & 36 \\
\hline & Average Score & 3.70 & 3.50 & 3.60 \\
\hline & Criteria & Very Valid & Very Valid & Very Valid \\
\hline
\end{tabular}

The results of the material expert validation showed that the quality of media developed was in the very valid category. The expert assessed that the media developed was in accordance with the curriculum in class VII of Deaf Junior High School, the concept had been properly presented, the systematic material had been integrated, the examples given were also correct in clarifying the concept, and the questions were clearly defined and the difficulty level in accordance with students. Some of the suggestions given to the improvement of the media there are (i) the actuality of the material still needs to be improved by linking the material with the current context, and (ii) the scope of the material needs to be expanded and the discussion carried out in more depth. 
Table 3

The Results of Media Aspect Validation

\begin{tabular}{|c|c|c|}
\hline No. & Media Aspect Assesment & Score \\
\hline A. & Software Aspect & \\
\hline 1. & Maintainable (can be maintained easily) & 3 \\
\hline 2. & Usable easy to be used and simple for the operation & 4 \\
\hline 3. & $\begin{array}{l}\text { Compatible (learning media can be installed or be run in various existing hardware } \\
\text { and software) }\end{array}$ & 3 \\
\hline 4. & Learning media operational & 4 \\
\hline 5. & $\begin{array}{l}\text { Reusable(some or all learning media programs can be used again to develop other } \\
\text { learning media) }\end{array}$ & 3 \\
\hline B. & Visual Communication Aspect & \\
\hline 6. & In accordance with a message and can be accepted with target desire & 4 \\
\hline 7. & Navigation in media operation & 3 \\
\hline 8. & Audio (narration, sound effects, back sound, music) & 4 \\
\hline 9. & Visual (layout design, typography, colour) & 3 \\
\hline 10. & Animation and picture in media & 4 \\
\hline & Total Score & 35 \\
\hline & Average Score & 3.50 \\
\hline & Criteria & Very valid \\
\hline
\end{tabular}

The results of the media expert validation showed that the quality of the media developed was in a Very Valid category. The expert considered that media developed had been usable, operational, communicative, and used the right audio and illustration. Some of the suggestions given for media improvement among others: (1) on CD packaging, adding competency formulas, program screenshots, usage instructions, minimum specifications, (2) autorun scripts to run programs automatically, (3) need to be added exit button (x ), (4) need to add a confirmation page, (5) fix the hint button script (?) Because there is an error in access to the main menu, and (6) you should add a button for audio control.

Table 4

The results of the Learning Design Validation Aspect

\begin{tabular}{|c|c|c|}
\hline No. & Learning design assessment aspect & Score \\
\hline 1. & Consistency between core competency, indicator, material, and evaluation & 4 \\
\hline 2. & Motivation presentation & 3 \\
\hline 3. & Material presentation system & 4 \\
\hline 4. & Clarity of material sequence & 4 \\
\hline 5. & Clarity of learning guidance & 3 \\
\hline 6. & Variation in presenting materials & 3 \\
\hline 7. & Example presentation & 3 \\
\hline 8. & Clarity of guidance for doing the test/task & 4 \\
\hline 9. & Task/test quality and its duty & 3 \\
\hline 10. & The balance between material and test/task & 4 \\
\hline 11. & The clarity of learning the purpose & 4 \\
\hline & Total Score & 39 \\
\hline & Average Score & 3.55 \\
\hline & Criteria & Very Valid \\
\hline
\end{tabular}

The results of the validation of learning design experts show that the quality of the media developed was in the Very Valid category. The expert considered that the media developed had been presented consistently and systematically. A description of learning objectives and the material was clear, and there was a balance of material with the task. Some of the suggestions provided for media improvement there are: (1) to clarify learning instruction and what they

Suarsana, I. M., Mahayukti, G. A., Sudarma, I. K., \& Yoga, I. N. B. A. (2018). Development of interactive mathematics learning media on statistics topic for hearing-impaired student. International Research Journal of Engineering, IT \& Scientific Research, 4(6), 55-66. https://doi.org/10.21744/irjeis.v4n6.377 
will learn from exploration media, and (2) so that when student answer questions, feedback should be given immediately.

Table 5

The results of language validation aspect

\begin{tabular}{|c|c|c|}
\hline No. & Assessment aspect & Score \\
\hline 1. & Sentence structure accuracy & 3 \\
\hline 2. & Rigidity term & 4 \\
\hline 3. & Sentence effectiveness & 3 \\
\hline 4. & The understanding of student to the delivered message & 3 \\
\hline 5. & The suitability of illustration with message substance & 4 \\
\hline 6. & The ability to motivate student & 3 \\
\hline 7. & The suitability with thinking development of student & 3 \\
\hline 8. & Spelling Accuracy & 3 \\
\hline 9. & The consistency of the term used & 2 \\
\hline 10. & The consistency of symbol used or icon & 3 \\
\hline & Total Score & 30 \\
\hline & Average Score & 3.00 \\
\hline & Criteria & Valid \\
\hline
\end{tabular}

The results of the linguistic validation indicated that the quality of the media developed was in the Valid category. The expert considered that the media developed had used standard terms and had used illustrations that are in accordance with the material substance. Some of the suggestions given for media improvement include : (1) so that the language used should be more simplified and (2) the words used should be more consistent that is using the same words to convey the same intent.

Based on Table 2 through Table 5, the results of media validation can be summarized as Table 6 . Thus the media developed had reached a very valid category. However, revisions were made according to the input of the five media validators.

Table 6

The conclusion of Media Validation

\begin{tabular}{|c|c|c|}
\hline No. & Assessment aspect & Score \\
\hline 1. & Sentence structure accuracy & 3.6 \\
\hline 2. & Term rigidity & 3.5 \\
\hline 3. & Sentence effectiveness & 3.55 \\
\hline 4. & Understanding of participants into the message delivered & 3 \\
\hline & Total Score & 13.65 \\
\hline & Average Score & 3.4125 \\
\hline & Criteria & Very Valid \\
\hline
\end{tabular}

\subsection{Analysis}

The results of media validation from the material aspects, media aspects, and learning design aspects showed that the media is categorized as very valid, while the results of the language expert's validation indicated that the media developed were Valid. Overall, based on the accumulation of scores as shown in Table 6, the average media validation score was 3.4125 which means that in general, the quality of the media was very valid. Therefore this media can be referred to as a prototype and was feasible to proceed to the next development stage, namely limited trials and field trials and product dissemination and packaging to be carried out the following year.

These initial results will enrich the learning resources of mathematics specifically for hearing-impaired students according to Mohid \& Zin (2010) whose existence is still very rare. The development of interactive learning media for hearing-impaired students that has been available so far is more in the form of sign language recognition material 
(Aziz et al., 2011; Saud \& Nasruddin, 2016; Dawis, 2013; Gunawan \& Salim, 2013). Several other researchers have also tried to develop interactive media for subjects such as (1) Effendi (2016) who has developed interactive learning media for science learning, and (2) Marzal (2014) who has developed interactive media for English lessons. Thus the existence of the media developed through this research will complement previous interactive media development studies specifically for hearing-impaired students.

The use of learning media for hearing-impaired students is something that absolutely must be sought to enable hearing-impaired students to have difficulty understanding the teacher's utterances fully. STR is often called visual learners because they absorb more information by looking at using their visual senses (Pariatin and Ashari, 2014; Chen, 2014). Therefore learning material should be made simple and equipped with visual representations (Malatista and Sediyono, 2012; Hopkins and Moore, 2010). In this study, the interactive media developed had accommodated the characteristics of hearing-impaired students by providing a higher proportion of visual approach in explaining a material using videos, images, and computer simulation. The video was made interestingly by displaying real condition, illustrations of mathematical objects correctly, and packaged in contexts that are close to students' everyday life so that media messages can be captured by students. The language used in the media had been validated by linguists for hearing-impaired students, who have provided many inputs regarding the use of simple sentences and consistent vocabulary so that students easily understand messages from the media.

Thus through this research development had been produced interactively with very valid criteria (good minimum quality). But the practicality and effectiveness of the media in improving the mathematics learning outcomes of hearing-impaired students had not been studied. Therefore it is necessary to do the next stage of research in the form of limited trials and field tests to prove it empirically that the media developed is effective in improving the mathematics learning outcomes of seventh-grade students in the Deaf Junior High School.

\section{Conclusion}

Based on the results of the research and discussion, it can be concluded that the prototype of the interactive mathematics learning media for statistical topics developed had met very valid criteria. The expert had provided feasibility assessment with very valid quality, the feasibility assessment of the media with very valid quality, the feasibility assessment of learning design with very valid quality, and the assessment of the feasibility of the language with valid quality. Thus this interactive media was declared feasible to proceed to the next research stage.

Conflict of interest statement and funding sources

The authors declared that's they have no competing interest. The study was financed by The Directorate Research and Social Service, Ministry of Research, Technology, and Higher Education.

\section{Statement of authorship}

The authors have a responsibility for the conception and design of the study. The authors have approved the final article.

\section{Acknowledgments}

The author would like to thank The Directorate Research and Social Service, Ministry of Research, Technology, and Higher Education for their financial support that this research was successfully undertaken. 


\section{References}

Akpinar, Y. (2008). validation of a learning object Review Instrument: Relationship between Ratings of learning objects and Actual learning outcomes. Interdisciplinary Journal of E-Learning and Learning Objects, (4), 291303.

Aziz, N. N., Shaffiei, Z. A., Roseli, N. H. M., Aziz, N. U. A., Mutalib, A. A., \& Jaafar, M. S. (2011). Assistive Courseware for Hearing Impaired Learners in Malaysia. International Journal on Advanced Science, Engineering and Information Technology, 1(2), 133-138.

Chen, Y. T. (2014). A study to explore the effects of self-regulated learning environment for hearing-impaired students. Journal of computer assisted learning, 30(2), 97-109.

Dawis, A. M. (2013). Perancangan Aplikasi Multimedia untuk Pengenalan Bahasa Isyarat bagi Anak Tuna Rungu Umur 6-9 Tahun (Doctoral dissertation, Universitas Muhammadiyah Surakarta).

Effendi, D. (2014). Program Aplikasi Pembelajaran IPA MAteri Sistem Peredaran Darah Manusia untuk Siswa Kelas V SDLB Bagian B (Tuna Rungu) Berbasis Multimedia.

Gunawan, A. A., \& Salim, A. (2013). Pembelajaran Bahasa Isyarat Dengan Kinect Dan Metode Dynamic Time Warping. Jurnal Mat Stat, 13(2), 77-84.

Hopkins, K., \& Moore, B. C. (2010). Development of a fast method for measuring sensitivity to temporal fine structure information at low frequencies. International Journal of Audiology, 49(12), 940-946.

Kirna, I Made. 2011. Jenis Multimedia serta Integrasinya dalam Pembelajaran. Diktat Perkuliahan Multimedia (unpublished). Undiksha: Singaraja

Liu, C. C., Chou, C. C., Liu, B. J., \& Yang, J. W. (2006). Improving mathematics teaching and learning experiences for hard of hearing students with wireless technology-enhanced classrooms. American Annals of the Deaf, 151(3), 345-355.

Malatista, B. R., \& Sediyono, E. (2012). Model Pembelajaran Matematika untuk Siswa Kelas IV SDLB Penyandang Tunarungu dan Wicara dengan Metode Komtal Berbantuan Komputer. Jurnal Informatika, 7(1), p-7.

Marzal, J. (2014). Desain Media Pembelajaran Bahasa Inggris Untuk Siswa Tunarungu Berbantuan Teknologi Informasi Dan Komunikasi. Jurnal Tekno-pedagogi, 4(2).

Mohid, S. Z., \& Zin, N. A. M. (2010, June). Courseware accessibility for hearing impaired. In Information Technology (ITSim), 2010 International Symposium in (Vol. 1, pp. 1-5). IEEE.

Mulyadi. (2015). Pembelajaran matematika di SLB Khusus Tuna Rungu Karnnamnohara Yogyakarta Tingkat SMP. (unpublished). UNY: Yogyakarta

Nunes, T., \& Moreno, C. (2002). An intervention program for promoting deaf pupils' achievement in mathematics. Journal of Deaf Studies and Deaf Education, 7(2), 120-133.

Pariyatin, Y., \& Ashari, Y. Z. (2014). Perancangan Media Pembelajaran Interaktif Mata Pelajaran PKN untuk Penyandang Tunarungu Berbasis Multimedia (Studi Kasus di Kelas VII SMPLB Negeri Garut Kota). Jurnal Algoritma, 11(1).

Rapin, I. (1986). Helping hearing-impaired students acquire language: Lessons from the past. International journal of pediatric otorhinolaryngology, 11(2), 213-223.

Saud, S. F., \& Nasruddin, Z. A. (2016, August). Design of e-learning courseware for hearing impaired (HI) students. In User Science and Engineering (i-USEr), 2016 4th International Conference on (pp. 271-276). IEEE.

Suharsimi, A. (2006). Prosedur penelitian suatu pendekatan praktik. Jakarta: Rineka Cipta.

Suwastarini, N. N., DANTES, D. N., CANDIASA, D. I. M., \& Komp, M. I. (2015). Pengaruh Implementasi Pembelajaran Berbasis Media Teknologi Informasi dan Komunikasi terhadap Motivasi dan Hasil Belajar Matematika Siswa Sdlb B (Tuna Rungu) pada Slb B Negeri Ptn Jimbaran. Jurnal Penelitian dan Evaluasi pendidikan Indonesia, 5(1).

Tanridiler, A., Uzuner, Y., \& Girgin, U. (2015). Teaching and learning mathematics with hearing impaired students. The Anthropologist, 22(2), 237-248.

Thiagarajan, S. (1974). Instructional development for training teachers of exceptional children: A sourcebook.

Wahono, R. S. (2006). Aspek dan kriteria penilaian media pembelajaran. On Line at http://romisatriawahono. net.[diunduh tanggal 10 April 2010].

Widana, I. W., Parwata, I. M. Y., Parmithi, N. N., Jayantika, I. G. A. T., Sukendra, K., \& Sumandya, I. W. (2018). Higher Order Thinking Skills Assessment towards Critical Thinking on Mathematics Lesson. International Journal of Social Sciences and Humanities (IJSSH), 2(1), 24-32.

Yamasari, Y. (2010). Pengembangan Media Pembelajaran Matematika Berbasis ICT yang Berkualitas. In Seminar Nasional Pascasarjana X-ITS. FMIPA Unesa. 
Yang, H. J., Lay, Y. L., Liou, Y. C., Tsao, W. Y., \& Lin, C. K. (2007). Development and evaluation of computer-aided music-learning system for the hearing impaired. Journal of Computer Assisted Learning, 23(6), 466-476.

Suarsana, I. M., Mahayukti, G. A., Sudarma, I. K., \& Yoga, I. N. B. A. (2018). Development of interactive mathematics learning media on statistics topic for hearing-impaired student. International Research Journal of Engineering, IT \& Scientific Research, 4(6), 55-66. https://doi.org/10.21744/irjeis.v4n6.377 


\section{Biography of Authors}

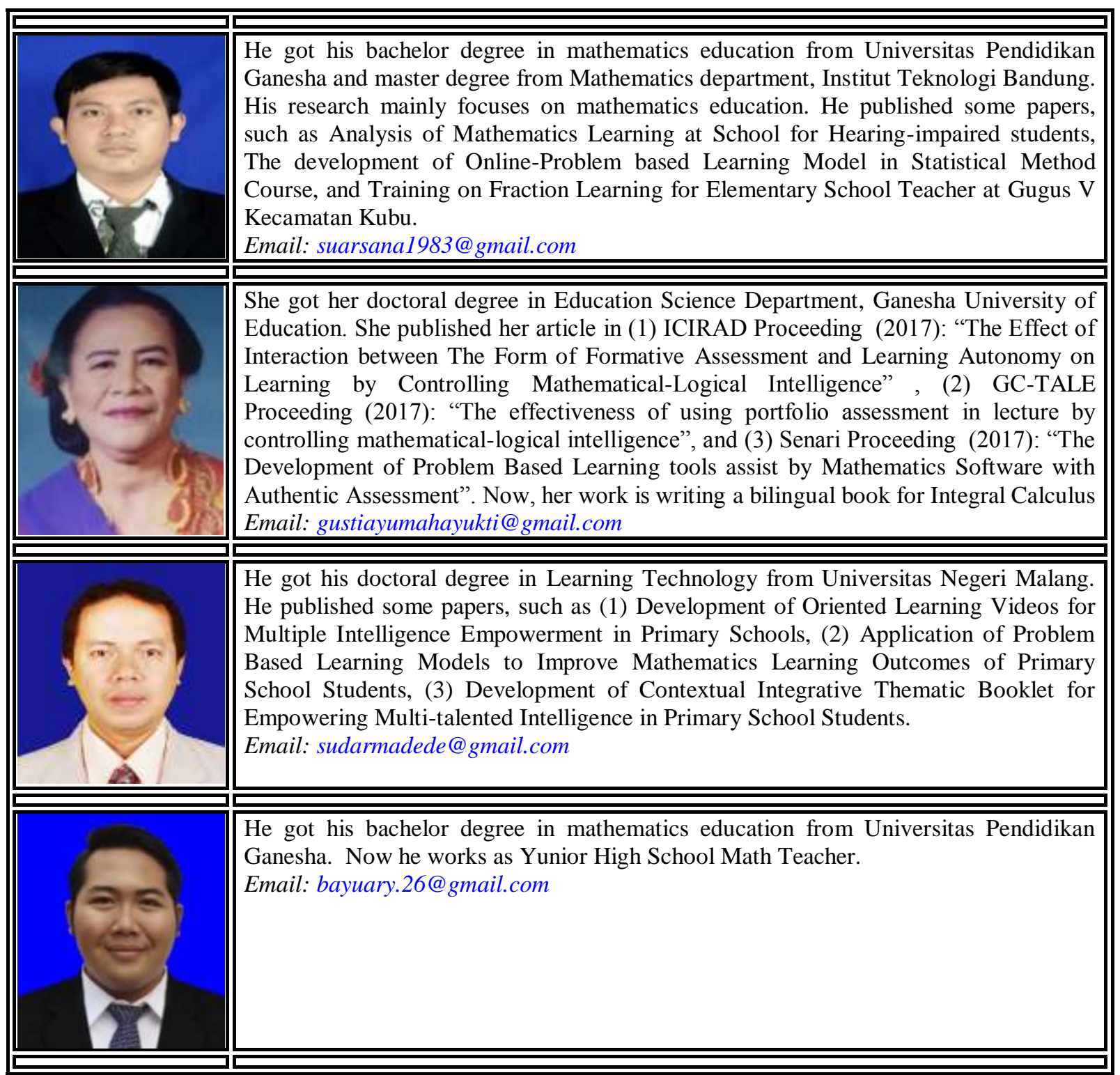

